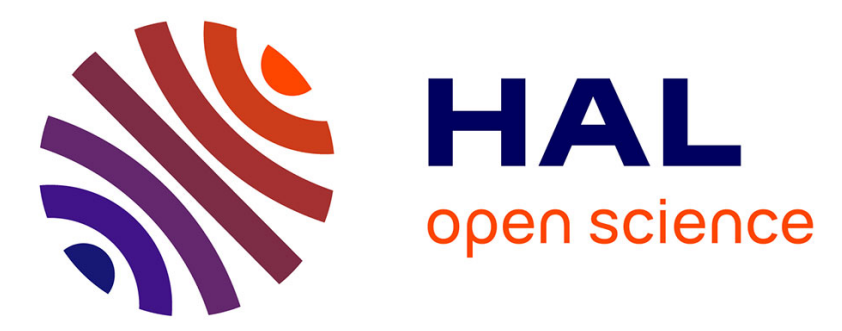

\title{
Rhizosphere effect is stronger than PAH concentration on shaping spatial bacterial assemblages along centimetre-scale depth gradients
}

\author{
Amélia Bourceret, Corinne Leyval, François Thomas, Aurélie Cebron
}

\section{- To cite this version:}

Amélia Bourceret, Corinne Leyval, François Thomas, Aurélie Cebron. Rhizosphere effect is stronger than PAH concentration on shaping spatial bacterial assemblages along centimetre-scale depth gradients. Canadian Journal of Microbiology, 2017, 63 (11), pp.881 - 893. 10.1139/cjm-2017-0124 . hal-01930946

\section{HAL Id: hal-01930946 \\ https://hal.science/hal-01930946}

Submitted on 13 May 2020

HAL is a multi-disciplinary open access archive for the deposit and dissemination of scientific research documents, whether they are published or not. The documents may come from teaching and research institutions in France or abroad, or from public or private research centers.
L'archive ouverte pluridisciplinaire HAL, est destinée au dépôt et à la diffusion de documents scientifiques de niveau recherche, publiés ou non, émanant des établissements d'enseignement et de recherche français ou étrangers, des laboratoires publics ou privés. 


\section{Rhizosphere effect is stronger than PAH concentration on shaping}

\section{spatial bacterial assemblages along centimeter-scale depth}

\section{gradients}

Amélia BOURCERET ${ }^{1,2, \dagger}$, Corinne LEYVAL ${ }^{1,2}$, François THOMAS ${ }^{1,2, \S}$, Aurélie

$$
\mathrm{CÉBRON}^{1,2, *}
$$

${ }^{1}$ CNRS, LIEC UMR7360, Faculté des Sciences et Technologies, Bd des Aiguillettes, BP70239, 54506 Vandoeuvre-lèsNancy, France.

${ }^{2}$ Université de Lorraine, LIEC UMR7360, Faculté des Sciences et Technologies, Bd des Aiguillettes, BP 70239,54506 Vandoeuvre-lès-Nancy, France.

*Corresponding author: aurelie.cebron@univ-lorraine.fr ; phone: (+33) 383684296.

${ }^{\dagger}$ Current address: Department of Plant Microbe Interactions, Max Planck Institute for Plant Breeding Research, Cologne, Germany

$\S$ Current address: Sorbonne Université, UPMC, Centre National de la Recherche Scientifique, UMR 8227, Integrative Biology of Marine Models, Station Biologique de Roscoff, Roscoff, France

Running-head: Rhizosphere bacterial assemblage at centimeter-scale 


\section{Canadian Journal of Microbiology}

\section{Résumé}

A l'échelle centimétrique, les paramètres biotiques et abiotiques (caractéristiques édaphiques et polluants) modulent les assemblages bactériens. Dans une expérience en rhizotron sur un sol industriel contaminé en hydrocarbures aromatiques polycycliques (HAP) et végétalisé, nous avons précédemment montré que la pollution était distribuée spatialement de manière aléatoire et avec des points chauds. Nous avons donc étudié ici l'effet de cette distribution hétérogène des HAP sur l'assemblage de la communauté bactérienne à l'échelle centimétrique, et l'avons comparé à l'impact des gradients rhizosphériques formés en fonction de la profondeur, en présence de luzerne ou ray-grass. Le séquençage d'amplicons d'ARNr $16 \mathrm{~S}$ a permis de montrer une plus grande diversité bactérienne dans la rhizosphère du ray-grass et un enrichissement en certains taxons selon le type de plante. En effet, les Bacteroidetes, Firmicutes et Gamma-Proteobacteria ont été favorisés dans la rhizosphère de la luzerne alors que le ray-grass a favorisé les Acidimicrobiia, Chloroflexi, Alpha- et BetaProteobacteria. Dans la rhizosphère de la luzerne, les gradients de biomasse racinaire, de concentrations en sucres et du $\mathrm{pH}$ en fonction de la profondeur, ont fortement modulé l'assemblage de la communauté microbienne, en favorisant les Actinobacteria en surface, et les Gemmatimonadetes et Proteobacteria en profondeur. Au contraire, la structure de la communauté bactérienne était homogène sur toutes les profondeurs dans la rhizosphère du ray-grass. Pour les 2 plantes, ni la concentration ni la distribution spatiale des HAP n'a d'effet significatif sur l'assemblage des communautés bactériennes. Globalement à l'échelle centimétrique, l'assemblage des communautés bactériennes est principalement modulé par les gradients physiques et chimiques induits par les systèmes racinaires mais pas par la pollution en HAP répartie de manière inégale.

\section{Abstract}

At centimeter scale, soil bacterial assemblages are shaped by both abiotic (edaphic characteristics and pollutants) and biotic parameters. In a planted industrial soil, contaminated with polycyclic aromatic hydrocarbons (PAHs), pollution was previously shown to be distributed randomly with hot and cold spots, using rhizoboxes. We therefore investigated the effect of this patchy PAH distribution on the bacterial community assemblage, and compared it to that of root depth gradients found in the rhizosphere of either alfalfa or ryegrass. Sequencing of 16S rRNA amplicons revealed a higher bacterial diversity in ryegrass rhizosphere and enrichment in specific taxa by the two plant species. Indeed, Bacteroidetes, Firmicutes and Gamma-Proteobacteria were globally favored in alfalfa while Acidimicrobiia, Chloroflexi, Alpha- and Beta-Proteobacteria were globally favored in 
55 ryegrass rhizosphere. The presence of alfalfa that created depth gradients of root biomass, carbohydrate and $\mathrm{pH}$,

56 actually shaped bacterial assemblage, favoring Actinobacteria near the surface, and Gemmatimonadetes and

57 Proteobacteria at greater depth, while it was spatially homogeneous all along the ryegrass root system. With

58 both plant species, the PAH content and random distribution had no significant effect on bacterial assemblage.

59 Globally, at cm-scale, bacterial community assemblages were mostly shaped by soil physical and chemical depth

60 gradients induced by root growth but not by PAH patchy content.

61

62 Keywords: Alfalfa, ryegrass, pyrosequencing, bacterial diversity, PAH-contaminated soil, rhizobox 
64

65

66 Identifying patterns and drivers of microbial heterogeneity in soil is one of the main current challenges in

\section{Introduction}

microbial ecology. Spatial patterns of soil microbial communities are extremely variable across scales (Ettema and Wardle, 2002; Tripathi et al. 2014; Fuka et al. 2009; Kuzyakov and Blagodatskaya 2015). At regional scale (meter to kilometer) factors such as climate, topography and soil pedology explain microbial community biogeography (Constancias et al. 2015a,b; Fierer and Jackson 2006; Dequiedt et al. 2011). At the field scale, Naveed et al. (2016) showed that bacterial community structure was not random but strongly related with edaphic properties, such as total organic carbon and clay content and soil water characteristics. At local scale (millimeter to centimeter), heterogeneity is driven by the patchy distribution of physico-chemical characteristics, carbon and nutrient resources and biotic and/or abiotic stressors, creating a mosaic of different habitats (Bahram et al. 2015; Ettema and Wardle, 2002). At centimeter scale O’Brien et al. (2016) observed an extreme patchiness with abrupt changes in relative abundance of bacterial phyla from sample to sample. At micrometer scale, spatial distribution of soil microbes is determined by microscale soil heterogeneity caused by variation in soil architecture, water fluxes and biotic interactions in aggregates and pore space (Nunan et al. 2002; Grundmann 2004; Stolpovsky et al. 2012; Raynaud and Nunan 2014). At all these scales, the presence of plants can further increase the spatial heterogeneity of microbial communities. Indeed, the rhizosphere soil compartment is a hotspot of microbial density and activity (Marschner et al. 2001; Garbeva et al. 2008). Plant roots create specific microniches (eg. oxygen concentration, $\mathrm{pH}$, available substrates, chemical signals) that can regulate microbial community structure (Jaeger et al. 1999; Hinsinger et al. 2009). In planted soils, microbiome structure and activity vary according to plant species (Berg and Smalla 2009), stages of plant development (Remenant et al. 2009; Philippot et al. 2013; Schmidt and Eickhorst 2014) and differences in quality and quantity of root exudates released by young, mature or senescent roots (Yang and Crowley 2000; Marschner et al. 2002; DeAngelis et al. 2009; Schmidt and Eickhorst 2014). However, little information is currently available on the spatial assemblage of soil microbial community in the rhizosphere of different plant species harboring contrasted root architectures and releasing various exudates. Such an approach should be studied at the millimeter to centimeter scale corresponding to the distance of rhizosphere influence.

The picture becomes even more complex when considering anthropogenized soils. Organic pollutants are recognized as one major bacterial community stressor and induce shifts in bacterial community composition 
94 (Yang et al. 2014). Polycyclic aromatic hydrocarbon (PAH) contamination also selects populations especially adapted for degradation (Cébron et al. 2008; Yrjälä et al. 2010). The distribution of persistent organic pollutants has been demonstrated to be patchy, therefore emphasizing the relevance of scale consideration for microbial ecology studies in urban zones and industrial polluted soils. At regional scale, pollution presents gradients of concentration decreasing spatially from the source points from urban and industrialized area to more rural zones (Peng et al. 2016). At the field scale, spatial patchy distribution of pollution can be found, influencing the relative proportion of some bacterial phyla (Mukherjee et al. 2014), as well as microbial diversity, evenness and PAH catabolic genes (Bengtsson et al. 2013). At local centimeter-scale, organic matter and pollutants are heterogeneously distributed and can form hotspots of concentration, conducting to a nugget effect (Bourceret et al. 2015, Hybolt et al. 2011). Unfortunately, the link between PAH hotspots and variation of community assemblage was never explored at this scale and needs to be specified. At smaller scale, diffusion mechanisms control the heterogeneity, but knowledge is limited by methodological flows due to the minimum quantity of soil necessary for organic pollutant analyses.

Interest is rising on the use of plants to treat PAH-polluted soils through rhizoremediation, by stimulating microorganism capacity to degrade pollutants in the rhizosphere (Kuiper et al. 2004). However, reports on rhizoremediation efficiencies vary, with sometime even inhibition of PAH-biodegradation in the rhizosphere of certain plants. Indeed plants select specific microbial communities depending on species (Kowalchuk et al. 2002), and different plants could preferentially enrich PAH-degraders (Siciliano et al. 2003; Kirk et al. 2005; Liste and Prust 2006; Cébron et al. 2009). Then, in polluted soils, the root zone could contribute to microbial community heterogeneity. In the past, most studies on rhizosphere microbiome overlooked this small-scale heterogeneity, comparing a composite sample of rhizosphere soil collected from a whole plant root system (e.g. plants collected in situ or cultivated in pots) to another plant species or to bulk or unplanted soils (Smalla et al. 2001; Yergeau et al. 2014; Breidenbach and Conrad 2015). Unfortunately, this one-dimensional approach does not inform on spatial heterogeneity and selection of specific microbial community assemblage depending on the plant species, the depth along the root system, the stage of plant development, the root biomass and age, and does not allow understanding rhizosphere soil biological functioning and processes. Based on these considerations, the impact of contrasted root architectures, and root density on shaping the microbial community structure should be investigated at the local centimeter scale to give insight into the rhizosphere influence, that has been demonstrated to extend to 10-20 millimeters from roots (Schmidt and Eickhorst 2013; Uteau et al. 
124 2015). As such specific patterns have not yet been analyzed or discussed for the spatial distributions of bacterial 125 taxa in the rhizosphere of PAH-polluted soils at fine cm-scale, we wanted to fill this gap. The development of 126 root window-based approaches, such as rhizoboxes, has opened new ways to reveal the distribution of microbes 127 in rhizosphere soil and have been used in the present study to sample numerous soil cores close to the roots and spatially distributed at different depths.

129

130 The present study focuses on the bacterial community structure along two plant root systems (alfalfa and ryegrass) in a PAH-contaminated soil in order to point out the principal environmental biotic and abiotic drivers at centimeter scale using rhizobox experimental device. Spatial variability of bacterial community has been rarely studied in the past, at small scale, and never in contaminated soil presenting spatial patchy distribution of pollutants and depth rhizosphere gradients as found in Bourceret et al. (2015). Based on these previous findings, we hypothesized that bacterial community could be influenced by two main forcing factors identified previously: i) rhizosphere processes linked to plant species and root depth gradients of root biomass and carbon from exudates, and/or ii) pollutant content that shows a random spatial distribution with cold and hot spots of PAHs. To test these hypotheses, we used tag-encoded amplicon pyrosequencing of bacterial 16S rRNA genes to investigate bacterial community assemblages in samples from rhizobox experiment.

Materials and methods

Aged PAH-contaminated industrial soil, collected from a former coking plant site (Neuves-Maisons [NM], Lorraine, France), was used for the same rhizobox experiment as described in Bourceret et al. (2015). The NM

148 industrial soil contains an historical and recalcitrant PAH contamination, ca 1224 mg. $\mathrm{kg}^{-1}$ (Cébron et al. 2009; 149 Ouvrard et al. 2011) of the 16 US-EPA PAHs. Briefly, rhizoboxes were poly-methyl-methacrylate boxes (H: 30 $150 \mathrm{~cm} \times$ D: $30 \mathrm{~cm} \times \mathrm{W}: 2.5 \mathrm{~cm})$ with a removable front face, and holes $(0.4 \mathrm{~cm}$ in diameter) at the bottom to allow water flow. Two rhizoboxes were filled with sieved NM soil, previously spiked with a complex organic pollutant extract from the same soil that increased the PAH content to $1524 \mathrm{mg} \cdot \mathrm{kg}^{-1}$ of 16 US-EPA PAHs and increased the bioavailability of PAHs and their biodegradation. Rhizoboxes were watered to $80 \%$ water retention capacity 
154 (WRC). At the start of the experiment, soil properties were spatially homogeneous in the two rhizoboxes..

155 Rhizoboxes were used to grow two plant species with contrasted root systems. After sowing alfalfa (Alf;

156 Medicago sativa var. Europe) and ryegrass (Rye; Lolium multiflorum var. Podium) at $22.3 \pm 2.0$ seeds per $\mathrm{cm}^{2}$, 157 plants were grown in a regulated growth chamber $\left(22^{\circ} \mathrm{C} / 18^{\circ} \mathrm{C}\right.$ day/night, $80 \%$ relative humidity, ca $250 \mu \mathrm{mol}$

158 photons $\mathrm{m}^{-2} \mathrm{~s}^{-1}, 16$-hour photoperiod) (Bourceret et al. 2015). Rhizoboxes were opened after 37 days (T37) when

159 few roots reached the bottom of the rhizoboxes and root density gradients could easily be visualized for both

160 plants. At this time 16 soil cores $\left(1.6 \mathrm{~cm}\right.$ diameter, $2.5 \mathrm{~cm}$ long; ca $\left.5.03 \mathrm{~cm}^{3}\right)$ were sampled every $6 \mathrm{~cm}$ at 2,8 ,

16114 and 20-cm depth (4 replicate cores per depth) from each rhizobox (i.e. 32 samples). Given the high root

162 density measured in each core sample (Table S1), we considered that the entire soil was influenced by roots and

163 regarded it as rhizosphere. Roots were rinsed 3 times with sterile water to collect the root-adhering soil, and

164 weighed to measure the dry root biomass of each sample. Centrifugation of the first root rinsing water allowed

165 collecting the adhering soil that was weighed (mass of root-adherent soil) before being mixed to the rest of soil

166 core sample. Considering the totality of rhizobox samples, root biomass was similar between the two plants

167 (mean of 13 and $12 \mathrm{mg}(\mathrm{n}=28)$ for alfalfa and rye-grass, respectively; Table $\mathrm{S} 1)$. Although two depth gradients

168 were found, the one in alfalfa rhizosphere was more pronounced than the ryegrass one, due to higher root

169 biomass at $2 \mathrm{~cm}$ depth (Table S1). The ratio mass of root adherent to total soil sample was higher in ryegrass

170 than in alfalfa (Table S1). The 32 mixed soil samples were stored at $-80^{\circ} \mathrm{C}$ until analysis.

171 Soil samples were previously characterized (Bourceret et al. 2015) for some biotic and abiotic characteristics that are summarized in the Table S1. Bacterial abundance (16S rRNA gene copy number, measured through realtime quantitative PCR) was higher in alfalfa than in ryegrass rhizosphere, without depth gradient. Dissolved

174 organic carbon (DOC) and carbohydrates were measured from soil aqueous extract ( $1 / 5 \mathrm{w} / \mathrm{v}$ ratio) prepared for $175 \mathrm{pH}$ measurement, using TOC-meter and ion-exchange chromatography. $\mathrm{pH}$ was similar between the two plants,

176 with lower values at $2 \mathrm{~cm}$ depth. DOC was higher with alfalfa than with ryegrass, while carbohydrates such as 177 fructose and xylose were mostly detected with ryegrass. Although no DOC depth gradient was observed, 178 concentration of individual carbohydrates varied, $i e$. inositol was more concentrated at $2 \mathrm{~cm}$ depth in alfalfa than 179 in ryegrass rhizosphere, and mannitol was more concentrated at deeper depth in ryegrass than in alfalfa 180 rhizosphere. Total and bioavailable PAH concentration were measured using High-Pressure Liquid 181 Chromatography (HPLC) after Accelerated Solvent Extraction (ASE) using dichloromethane and 182 hydroxypropyl- $\beta$-cyclodextrin extraction, respectively. Although higher concentrations of the total and 183 bioavailable 16 US-EPA PAHs were observed in ryegrass than in alfalfa rhizosphere (Table S1), no depth 
184 gradient was shown because PAH were distributed randomly with patches of hot and cold spots (Bourceret et al. 185 2015).

186

187

188

189

190

191

192

193

194

195

196

197

198

199

200

201

202

203

204

205

206

207

208

209

210

211

212

213

\section{DNA Extraction}

Total genomic DNA (gDNA) was extracted from $c a 0.5 \mathrm{~g}$ wet weight of the 32 soil samples (16 samples for each plant after 37 days of growth: T37_alf and T37_rye), using the FastDNA SPIN Kit for Soil (MP Biomedicals, Illkirch, France) and resuspended in $100 \mu 1$ of Dnase-free water. A spectrophotometer (UV1800, Shimadzu) equipped with a TrayCell unit (Hellma) allowed measuring gDNA concentration and evaluating its quality (purity ratio $\mathrm{A}_{260} / \mathrm{A}_{280}$ ).

\section{Library preparation and pyrosequencing}

The V4-V5 region of bacterial 16S rRNA gene was amplified using the primer set 515F (5'-GTG CCA GCM GCC GCG GTA A-3') / 907R (5'-CCG TCA ATT CMT TTR AGT TT-3') (Turner et al. 1999), combined at the 5'-end with a MID (Multiplex IDentifier, Roche) corresponding to a sample identification sequence of 10 nucleotides. PCR reactions were performed for each sample in five replicates, in a final volume of $50 \mu 1$ containing $5 \mathrm{X}$ Taq- $\& \mathrm{Go}^{\mathrm{TM}}$ ready to use PCR Mix (MP Biomedicals, Illkirch, France), $10 \mathrm{pM}$ of each primer, and $2 \mu \mathrm{l}$ of ten-fold diluted template gDNA. Amplicons from the five independent reactions were pooled and purified using the QIAquick PCR Purification Kit (Qiagen, France). Amplicon concentration was measured on a spectrophotometer as described above for gDNA. An equimolar mix of the thirty-two 16S rRNA gene amplicons was prepared in a final volume of $50 \mu \mathrm{l}$, reaching a total concentration of $40 \mathrm{ng} . \mu \mathrm{l}^{-1}$. Library was sequenced by Beckman Coulter Genomics (Danvers, MA, USA) on a half run of 454/Roche GS-FLX Titanium system using Lib-L kit. Sequence data from the 32 samples have been deposited in the NCBI Sequence Read Archive (SRA) and are available under the BioProject ID: PRJNA305229.

\section{Analysis of $16 \mathrm{~S}$ rDNA sequences}

After a denoising step from fasta- and qual-files with Acacia 1.52-b0 program (Bragg et al. 2012) at the default 
214

parameters, a total of 565,240 16S rDNA sequences were retained. Denoised data were further analyzed in the QIIME 1.8.0 pipeline (Caporaso et al. 2010). First, sequences were distributed to the 32 samples according to their MIDs and filtered according to different criteria: a length between 300 and $500 \mathrm{bp}$, a minimum average quality score allowed in sequence of 25 , an absence of ambiguous bases and a maximum length of homopolymer runs of $6 \mathrm{bp}$. Both sense and non-sense sequences were included in the analysis. Second, sequences were clustered in Operational Taxonomic Units (OTUs) at 97\% of similarity using USEARCH program including chimera detection (Edgar 2010). Taxonomy was assigned to a representative sequence from each OTU, identified as the most abundant read, using RDP classifier (Wang et al. 2007) and the Greengenes 13 _5 database (McDonald et al. 2012). Finally, subsampling was performed to 3,223 sequences per sample, corresponding to the lowest number of sequences retrieved in one of the samples. Alpha-diversity indexes $\left(\mathrm{OTU}_{97}\right.$ and $\mathrm{Chao1}$ richness estimates, Shannon H' and inverse Simpson diversity indexes and Evenness) were calculated from this data set using QIIME 1.8.0 pipeline.

\section{Statistical analysis}

Differences in alpha-diversity estimates between groups were tested using Student t-test and one-way analyses of variance (ANOVA) followed by Newman-Keuls Tukey HSD multiple comparison Post-Hoc test in XLstat software version 2.01 (Addinsoft) with significance level set at $\mathrm{p}<0.05$. To evaluate the impact of soil characteristics (PAH concentration, root density and soil properties, among others) on the bacterial community structure, non-metric multidimensional scaling (nMDS) was performed in R (version 3.0.1) on a Bray-Curtis dissimilarity matrix by using pyrosequencing data at the OTU level for the two-plant species. Fitting of the soil characteristics was performed using the envfit function from the vegan package (Oksanen et al. 2013). After calculation of Pearson correlation between soil characteristics and bacterial diversity (Table S2), only significant factors $(p<0.05)$ were conserved for visualization. We took advantage of the soil biotic and abiotic characteristics previously published in Bourceret et al. (2015) and summarized above (Table S1). To evaluate differences in bacterial community structures between the two plant rhizospheres, subsequent statistical analyses were performed: i) Differences in the relative abundance of taxa composing the bacterial community depending on plant species were analyzed with STAMP version 2.0.8 (Parks and Beiko 2010) that allowed considering the effect size to evaluate the magnitude of the observed differences; ii) Welch's t-tests with filtering of the results based on effect size (difference between proportions $>1$ or ratio of proportions $>4$ ) were used to evaluate 
244 changes in relative abundance between the two plant conditions at T37. Finally, to evaluate the impact of root

245 depth gradient on bacterial community structures subsequent statistical analyses were performed: Discriminant

246 taxa between the four studied depths $(2,8,14$ and $20 \mathrm{~cm})$ inside alfalfa or ryegrass condition were identified

247 using an ANOVA followed by a Tukey-Kramer post-hoc comparison test, with filtering of the results based on

248 effect size eta ${ }^{2}>0.26$, that is considered as a large value (Nakagawa and Cuthill 2007). For Welch's tests and

249 ANOVA performed in STAMP, significance level was set at $\mathrm{q}=0.05$ after Benjamini-Hochberg correction for

250 multiple testing, and only taxa with relative abundance representing at least 3 sequences in one sample were

251 considered.

\section{Results and Discussion}

\section{Bacterial community description}

258 After quality-filtering and subsampling, a total of 103,136 16S rDNA sequences were clustered in 1,848 OTUs. OTUs represented by more than 3 sequences belonged to 12 known phyla (Fig. 1). In aged-contaminated environments, selection and adaptation processes lead to the development of a specific bacterial community tolerant to the pressure exerted by the pollution (Yang et al. 2014b, Golebiewski et al. 2014). This is in contrast with more recent pollution, which induces toxicity mechanisms (Yang et al. 2014a). Accordingly, the NM soil bacterial community is well adapted to contamination due to its long-term ( $c a 100$ years) PAH exposure (Cébron et al. 2009; Bourceret et al. 2016), but we could expect that PAH-spiking and biodegradation activity could have exerted a new pressure of selection combined to the plant growth, during the 37 days in rhizoboxes. As previously shown on in situ experimental plots planted with alfalfa, the NM soil is dominated by members of the Proteobacteria, Actinobacteria and Bacteroidetes phyla (Bourceret et al. 2016), followed by Chloroflexi and Planctomycetes. By gathering the twenty most abundant OTUs in both alfalfa and ryegrass conditions, we found that the bacterial community was dominated by 26 OTUs (accounted for $51.9 \pm 3.4 \%$ of the bacterial $16 \mathrm{~S}$ rDNA sequences), of which $70 \%$ belongs to Proteobacteria. Proteobacteria often dominates most soil bacterial communities (Fierer et al. 2007), but we notice here that Actinobacteria is the second dominant phylum group while usually it is in lower abundance in most soils (Janssen et al. 2006, Fierer et al. 2007). High proportion of spore forming bacterial group such as Actinobacteria, likely indicates an adaptation of the community to 
environmental stress imposed by multi-contamination in NM soil (Ouvrard et al. 2011). It has been described that Actinobacteria dominate in soils with $<10 \%$ organic matter whereas Proteobacteria prevailed in higherorganic matter soils (Bell et al., 2013). Even if NM soil has a high organic carbon content due to PAH contamination, it mainly consists of highly recalcitrant carbon (Biache et al. 2014) with low bioavailability. Furthermore, previous studies showed that Actinobacteria dominated in hydrocarbon and diesel-polluted soils (Yergeau et al. 2012; Bell et al. 2013) as some isolates are capable of hydrocarbon biodegradation (Kanaly and Harayama 2010). In NM soil, members of the Bacteroidetes were the third dominating group, while Janssen (2006) reported that they are generally in low abundance in soils and most of the time belong to the rarebiosphere (Nacke et al. 2011). Bacteroidetes were previously shown to be: i) negatively correlated with total soil carbon content, ii) more abundant in relatively high soil $\mathrm{pH}$, and iii) rapidly activated by easily degradable plant derived bio-available organic matter (Acosta-Martinez et al. 2010). These traits could explain the relatively high proportion of Bacteroidetes in alfalfa and ryegrass planted NM soil. The relative abundance of Acidobacteria $(<$ $0.71 \%$ ) was low in comparison with other soil types where it ranges from 2 to $78 \%$ (Jones et al. 2009). This could be explained by a mean $\mathrm{pH}$ of 7.3 and recent modification and adaptation of the NM soil community to the continual input of pollutants during the $20^{\text {th }}$ century. Indeed Acidobacteria are better adapted to environments with low pH (Fierer et al. 2007) and are scarce in young soils (Nemergut et al. 2007; Tarlera et al. 2008).

\section{Identification of parameters influencing the bacterial community assemblage}

Although the bacterial community composition of the NM soil was globally similar in both planted rhizoboxes, we asked whether it is specifically shaped by plant species and spatially structured according to rhizosphere depth gradient or heterogeneous patchy PAH distribution. Non-metric multidimensional scaling (nMDS, Fig. 2) based on relative abundances of OTUs revealed a clear distinction of bacterial community assemblage after 37 days of plant growth depending on plant species, along the first axis (dim1) that also discriminated samples according to sampling depth for alfalfa. The second axis (dim2) discriminated samples according to sampling depth for both alfalfa and ryegrass condition. Fitting of soil parameters to the ordination further showed that depth, bacterial abundance, root biomass, mass of root adherent soil (collected after washing the roots), $\mathrm{pH}$, dissolved organic carbon and carbohydrate contents (inositol, mannitol, xylose and fructose) were significantly correlated with bacterial community structure (see Pearson correlations in Table S2). Among these correlated parameters, the four most impacting were the depth, the mass of root-adherent soil, $\mathrm{pH}$ and bacterial abundance 
304 (Pearson correlation $\mathrm{R}^{2}=0.78,0.66,0.59$ and 0.56 , respectively; Table S2). DOC and bacterial abundance, 305 significantly higher in alfalfa rhizosphere, and carbohydrate quality (i.e. inositol concentration significantly 306 higher in alfalfa contrary to mannitol, fructose and xylose concentrations that were higher in ryegrass), were 307 linked to differences in bacterial diversity between the two plant species. $\mathrm{pH}$, depth and root biomass were correlated together and influenced similarly both rhizospheres. On the contrary, the total and bioavailable PAH concentrations were not significantly correlated with bacterial community structure (Fig. 2; Table S2). Although PAHs are randomly distributed, their concentrations are spatially variable in both rhizoboxes with local hot and cold spots, as well as higher variability and lower mean concentration in alfalfa than in ryegrass rhizosphere $(1074 \pm 359$ and $1297 \pm 340 \mathrm{mg} / \mathrm{kg}$ of total PAHs, respectively; Table S1). The PAH contamination was homogeneous at the beginning of the experiment with a low standard deviation (i.e. $1524 \pm 174 \mathrm{mg} / \mathrm{kg}$ of total PAHs, coefficient of variation $\mathrm{CV}=11 \%$ ), while after 37 days of PAH biodegradation a high heterogeneity appeared in both rhizoboxes $(\mathrm{CV}=33 \%$ and $26 \%$ for alfalfa and ryegrass, respectively). However the present data, supported by absence of Pearson correlation (Table S2), suggests that local variations in PAH content do not influence the NM soil bacterial community assemblage when comparing for each soil core sample, the PAH content and the bacterial diversity. Since the bacterial community has adapted to the pollution over decades (Cébron et al. 2009), a large fraction of the soil microbiome could be tolerant to high PAH concentration level, as shown in soils regularly exposed to PAHs (Macleod and Semple 2002; Haritash and Kaushik 2009). Therefore, the fate of PAH probably depends mainly on bacterial activity level (mRNA) that could locally be higher while diversity does not change (Johnsen and Karlson 2007; Thomas and Cébron 2016). Our data suggests that at centimeter-scale, rhizosphere effect was stronger than PAH concentration effect on spatially shaping bacterial assemblages. The pre-eminence of rhizosphere effect against PAH concentration contrasts with what was previously found at larger meter-scale where microbial diversity, evenness and the distribution of PAH catabolic genes matched the patchy PAH distribution (Bengtsson et al. 2013) and where abundance of some phyla (i.e. increase in Proteobacteria and decrease in Actinobacteria, TM7 and Planctomycetes) was linked to hot spots of PAH pollution (Mukherjee et al. 2014). Working at meter-scale, in the field, might underestimate the effect of plants due to limitation of sampling. A study at a smaller scale can be useful to consider the impact of rhizosphere that is spatially limited

331 by short-range diffusion of rhizodeposits in vegetated soils. Our finding highlights the urgent need of considering relevant, fine-scale effects when evaluating rhizosphere impact on pollutant biodegradation. 
335

336

\section{Plant species effect on the bacterial community}

We characterized the effect of plant species on shaping the rhizosphere bacterial communities by analyzing results from both rhizoboxes using the variability among the 16 sample points per condition after 37 days of plant growth. Technical constraints allowed investigating only one rhizobox per plant species, thus it is difficult to fully account for unexpected variations due to the rhizobox system itself. However, the two rhizoboxes were prepared simultaneously with the same batch of soil, previously sieved at $2 \mathrm{~mm}$, and kept under the same conditions. Furthermore at the finely sampled centimeter scale, we can consider that we compared two rhizosphere systems (containing each dozens of plants), one planted with alfalfa and the other with ryegrass (Kuske et al. 2002). All estimates of bacterial richness ( $\mathrm{p}=0.017$ and 0.001 for Chaol and $\mathrm{OTU}_{97}$, respectively), taxon evenness $(\mathrm{p}=0.003)$ and diversity $\left(\mathrm{p}=0.001\right.$ and 0.005 for $H^{\prime}$ and $1 / \mathrm{D}$, respectively) were significantly higher in soil planted with ryegrass compared to alfalfa (Table 1). As previously shown in Bourceret et al. (2015), root biomass was globally similar in both rhizobox (mean of $13 \mathrm{mg}$ dry roots, $\mathrm{n}=16$ ) but ryegrass roots were more homogeneously distributed all over the rhizobox than for alfalfa that had a higher root biomass at shallow depth $(2 \mathrm{~cm})$ in comparison to the three other greater depths ( $26 \pm 17$ and $9 \pm 5 \mathrm{mg}$, respectively). Thus, the commonly described rhizosphere impact (i.e. reduction of the alpha-diversity indices; Kowalchuk et al. 2002; Marilley and Aragno 1999) was less pronounced in ryegrass than in alfalfa rhizobox because alfalfa root biomass was higher. Although a higher ratio of root-adherent soil was detected for ryegrass than for alfalfa $(0.11 \pm 0.03$ and $0.04 \pm 0.02$, respectively), a higher dissolved organic carbon concentration $(190 \pm 65$ and $121 \pm 37 \mathrm{mg} / \mathrm{kg})$ and a higher bacterial abundance $\left(3.44 \times 10^{9} \pm 9.57 \times 10^{8}\right.$ and $2.37 \times 10^{9} \pm 5.60 \times 10^{8} 16 \mathrm{~S}$ rDNA copies, respectively) were detected in alfalfa than in ryegrass rhizosphere, respectively. Root structure, and concentration, composition and production rate of exudates, as well as nature of root symbiosis are the main factors driving bacterial colonization of the rhizosphere and bacterial community structure (Marschner et al. 2001; Berg and Smalla 2009). Indeed, the two studied plants possess a very contrasted root system (Bourceret et al. 2015). Alfalfa develops a tap root system composed of a central root from which few lateral roots emerge (Aprill and Sims 1990). Meanwhile ryegrass features an extensively branched and fibrous root system with fine and profuse roots, that leads to high root length and higher total rhizoplane surface than alfalfa (Soleimani et al. 2010). 
364 The effect of plant species was highlighted when taking relative abundance into account. At different taxonomic

365 levels (Table 2), members of the Bacteroidetes (Flavobacteriia class and Flavobacteriales order), Firmicutes

366 (Bacilli class, Bacillales order and Paenibacillus), Alpha-Proteobacteria (unclassified Caulobacteraceae,

367 Devosia, unclassified Sphingomonadaceae), Gamma-Proteobacteria (Pseudomonadales order and

368 Pseudomonas) and Actinobacteria (unclassified Micrococcaceae) were significantly more abundant in alfalfa

369 than in ryegrass rhizosphere. Reversely, members of the Chloroflexi, Alpha-Proteobacteria (Sphingomonadales

370 and Caulobacterales orders, and Mycoplana and unclassified Sphingomonadaceae), Beta-Proteobacteria

371 (Burkhorderiales and Hydrogenophilales orders, and Thiobacillus) and Actinobacteria (Acidimicrobiales order)

372 were significantly more abundant with ryegrass than with alfalfa (Table 2). Similarly, several studies showed

373 such species-dependent effect of plants on the assemblage of rhizosphere bacterial communities (Kirk et al.

374 2005; Kawasaki et al. 2012; Oliveira et al. 2014). Although additional unmeasured parameters might be of

375 importance (e.g. nitrogen content), we managed to establish relationships between bacterial community

376 assemblage and a number of soil characteristics (Fig. 2). Higher content of dissolved organic carbon in alfalfa

377 rhizosphere could explain the higher bacterial abundance compared to ryegrass. A positive correlation between

378 microbial biomass and water-soluble organic carbon was previously described and variability between plant species was observed (Chantigny et al. 1996). Although carbohydrates are not the main components of root exudates ( $\mathrm{ca} 5 \%$ of DOC), their analysis provides information about differences in the nature of compounds released by the two plant species. The higher inositol content in alfalfa rhizosphere (Bourceret et al. 2015) might select specific bacteria compared to ryegrass rhizosphere, which was richer in mannitol, xylose and fructose.

Spatial structuration of bacterial community assemblage with depth

We demonstrated here that the physical and chemical depth gradients, observed at centimeter-scale, shaped differentially the bacterial community under alfalfa and ryegrass systems. Some studies have shown that bacterial community structure is modified with stage of plant development (Chiarini et al. 1998; BauDoin et al. 2002) and position along the root (Baudoin et al. 2001; Cavaglieri et al. 2009), which both affect the quality of root exudates. So far, these studies focused mainly on the maize rhizosphere and on non-contaminated soil.

391 Working on the same dataset as the present experiment, Bourceret et al. (2015) previously indicated that the $\mathrm{pH}$ was positively correlated and the root biomass was negatively correlated with depth in rhizoboxes, and that carbohydrate concentrations varied both with plant species and depth. 
394 Ryegrass root biomass was relatively homogeneous along the depth profile. Accordingly we did not evidence spatial gradient of bacterial diversity (Table 1), nor did we identify OTUs impacted significantly with depth in ryegrass rhizosphere despite the presence of sugar gradients and a small trend of depth structuration in multivariate analysis (Fig. 2). These results contrast with previous observations on functional population, showing increased abundance of PAH-degrading Actinobacteria dioxygenase genes, with depth in ryegrass rhizosphere (Bourceret et al. 2015). On the contrary, all diversity estimators increased significantly with depth in the soil planted with alfalfa (Table $1 ; \mathrm{p}=0.003,0.001,0.017,0.029$ and 0.052 for $\mathrm{OTU}_{97}, \mathrm{Chao} 1, H, 1 / \mathrm{D}$ and $\mathrm{E}$, respectively). Furthermore, they were negatively correlated to alfalfa root biomass that was more abundant at shallow depth (Pearson's correlation coefficient $\mathrm{R}^{2}=-0.60,-0.61,-0.64,-0.54$ and -0.62 for $\mathrm{OTU}_{97}$, Chaol, $H^{\prime}, 1 / \mathrm{D}$ and $\mathrm{E}$, respectively). Exudation is known to be greater at the root apex, and hence expected to be higher at greater depth in alfalfa rhizobox due to its root structure. The quality of exudate compounds varies depending on the age of plant roots (Walker et al. 2003; Yang and Crowley 2000), thus creating depth gradient due to the presence of older roots at shallow depths. This phenomenon could explain the highest bacterial diversity at greater depth potentially due to differences in exudate quality. These results contrast with previous studies in non-contaminated soil, where root exudation leads to nutrient selection for fast-growing species and to a lower diversity (Kowalchuk et al. 2002; Marilley and Aragno 1999). Moreover, the relative abundance of some phyla and OTUs varied also significantly with depth in the soil from the alfalfa rhizobox (Fig. 1 and 3). Few authors suggested that spatial variability across the rhizosphere induces spatial gradient of bacteria, due to heterogeneity of nutrient release. For instance Corgié et al. (2006) observed in a compartmented device that bacterial community structure depended on the distance from roots. In alfalfa rhizobox, at phylum level, the relative abundance of Actinobacteria was significantly higher at shallow depth where root biomass and inositol content were higher and $\mathrm{pH}$ more acidic $(\mathrm{pH}$ was $6.91 \pm 0.22$ and $7.32 \pm 0.08$ at $2 \mathrm{~cm}$ depth and mean at the three deeper depths, respectively), while Gemmatimonadetes and Proteobacteria phyla were significantly more abundant at greater depth (Fig. 1). Five OTUs affiliated to Actinobacteria (unclassified Micrococcaceae), Bacteroidetes (unclassified Chitinophagaceae), Firmicutes (unclassified Bacillales), Planctomycetes (Planctomyces) and Alpha-Proteobacteria (unclassified Methylobacteriaceae) were significantly favored at shallow depth (Fig. 3). The slight acidification linked to the higher root biomass at shallow depth (Hinsinger et al. 2003) could select some taxa, as the $\mathrm{pH}$ was previously described as a main driver of bacterial community (Rousk et al. 2010). Five OTUs affiliated to Actinobacteria (unclassified Nocardioidaceae), Firmicutes (Bacillus selenatarsenatis), Alpha-Proteobacteria (unclassified 


\section{Canadian Journal of Microbiology}

Phyllobacteriaceae) and Gamma-Proteobacteria (unclassified Xanthomonadaceae) were significantly favored at greater depth (Fig. 3).

426

427

428

429

430

431

432

433

434

435

436

437

438 Acknowledgments: The authors have no conflict of interest to declare and thank the GISFI (www.gisfi.fr) for providing NM soil. This study was part of the RhizOrg project funded by the Agence Nationale de la Recherche

440 (ANR-13-JSV7-0007-01). Authors thank Dr. D. Blaudez and Dr. T. Beguiristain for their precious reviewing of 441 the manuscript.

442

443 Conflict of interest: The authors have no conflict of interest to declare.

445

446 


\section{References}

Acosta-Martinez, V., Dowd, S.E., Sun, Y., Wester, D., Allen, V. 2010. Pyrosequencing analysis for characterization of soil bacterial populations as affected by an integrated livestock-cotton production system. Appl. Soil Ecol. 45:13-25. Doi: 10.1016/j.apsoil.2010.01.005

Aprill, W., Sims, R.C. 1990. Evaluation of the use of prairie grasses for stimulating polycyclic aromatic hydrocarbon treatment in soil. Chemosphere 20:253-265. Doi: 10.1016/0045-6535(90)90100-8

Bahram, M., Peay, K.G., Tedersoo, L. 2015. Local scale biogeography and spatiotemporal variability in communities of mycorrhizal fungi. New Phytol. 205:1454-1463. Doi: 10.1111/nph.13206

Baudoin, E., Benizri, E., Guckert, A. 2001. Metabolic fingerprint of microbial communities from distinct maize rhizosphere compartments. Eur. J. Soil Biol. 37:85-93. Doi: 10.1016/S1164-5563(01)01071-8

Baudoin, E., Benizri, E., Guckert, A. 2002. Impact of growth stage on the bacterial community structure along maize roots, as determined by metabolic and genetic fingerprinting. Appl. Soil Ecol. 19:135-145. Doi: 10.1016/S0929-1393(01)00185-8

Bell, T.H., Yergeau, E., Maynard, C., Juck, D., Whyte, L.G., Greer, C.W. 2013. Predictable bacterial composition and hydrocarbon degradation in Arctic soils following diesel and nutrient disturbance. ISME J. 7:1200-1210. Doi: 10.1038/ismej.2013.1

Bengtsson, G., Törneman, N., Lipthay, J., Sørensen, S. 2013. Microbial diversity and PAH catabolic genes tracking spatial heterogeneity of PAH concentrations. Microb. Ecol. 65:91-100. Doi: 10.1007/s00248012-0112-0

Berg, G., and Smalla, K. 2009. Plant species and soil type cooperatively shape the structure and function of microbial communities in the rhizosphere. FEMS Microbiol. Ecol. 68:1-13. Doi: 10.1111/j.15746941.2009.00654.x

Biache, C., Mansuy-Huault, L., Faure, P. 2014. Impact of oxidation and biodegradation on the most commonly used polycyclic aromatic hydrocarbon (PAH) diagnostic ratios: implications for the source identifications. J. Hazard. Mat. 267:31-39. Doi : 10.1016/j.jhazmat.2013.12.036

Bourceret, A., Cébron, A., Tisserant, E., Poupin, P., Bauda, P., Beguiristain, T., Leyval, C. 2016. The bacterial and fungal diversity of an aged PAH-and heavy metal-contaminated soil is affected by plant cover and edaphic parameters. Microb. Ecol. 71:711-724. Doi:10.1007/s00248-015-0682-8

Bourceret, A., Leyval, C., De Fouquet, C., Cébron, A. 2015. Mapping the centimeter-scale spatial variability of PAHs and microbial populations in the rhizosphere of two plants. PloS one, 10:e0142851. Doi: 10.1371/journal.pone.0142851

Bragg, L., Stone, G., Imelfort, M., Hugenholtz, P., Tyson, G.W. 2012. Fast, accurate error-correction of amplicon pyrosequences using Acacia. Nat. Meth. 9:425-426. Doi:10.1038/nmeth.1990

Breidenbach, B., and Conrad R. 2015. Seasonal dynamics of bacterial and archaeal methanogenic communities in flooded rice fields and effect of drainage. Front. Mic. 5:752. Doi: 10.3389/fmicb.2014.00752

Caporaso, J.G., Kuczynski, J., Stombaugh, J., Bittinger, K., Bushman, F.D., Costello, E.K., et al. 2010. QIIME allows analysis of high-throughput community sequencing data. Nat. Methods 7:335-336. Doi:10.1038/nmeth.f.303 
Cavaglieri, L., Orlo, J., Etcheverry, M. 2009. Rhizosphere microbial community structure at different maize plant growth stages and root locations. Microbiol. Res. 164:391-399. Doi: 10.1016/j.micres.2007.03.006

Cébron, A., Norini, M.P., Beguiristain, T., Leyval, C. 2008. Real-Time PCR quantification of PAH-ring hydroxylating dioxygenase (PAH-RHD $\alpha$ ) genes from Gram positive and Gram negative bacteria in soil sediment samples. J. Microbiol. Meth. 73:148-159. Doi: 10.1016/j.mimet.2008.01.009

Cébron, A., Beguiristain, T., Faure, P., Norini, M.P., Masfaraud, J.F., Leyval, C. 2009. Influence of vegetation on the in situ bacterial community and polycyclic aromatic hydrocarbon (PAH) degraders in aged PAHcontaminated or thermal-desorption-treated soil. Appl. Environ. Microbiol. 75:6322-6330. Doi : 10.1128/AEM.02862-08

Chantigny, M., Prévost, D., Angers, D., Vézina, L.P., Chalifour, F.P. 1996. Microbial biomass N transformations in two soils cropped with annual perennial species. Biol. Fertil. Soils 21:239-244. Doi: 10.1007/BF00334898

Chiarini, L., Bevivino, A., Dalmastri, C., Nacamulli, C., Tabacchioni, S. 1998. Influence of plant development, cultivar and soil type on microbial colonization of maize roots. Appl. Soil. Ecol. 8:11-18. Doi: 10.1016/S0929-1393(97)00071-1

Constancias, F., Saby, N.P.A., Terrat, S., Dequiedt, S., Horrigue, W., Nowak, V., et al. 2015a. Contrasting spatial patterns and ecological attributes of soil bacterial and archaeal taxa across a landscape. MicrobiologyOpen. 4:518-531. Doi: 10.1002/mbo3.256

Constancias, F., Terrat, S., Saby, N.P.A., Horrigue, W., Villerd, J., Guillemin, J.P., et al. 2015b. Mapping and determinism of soil microbial community distribution across an agricultural landscape. MicrobiologyOpen. 4:505-517. Doi: 10.1002/mbo3.255

Corgié, S.C., Beguiristain, T., Leyval, C. 2006. Differential composition of bacterial communities as influenced by phenanthrene and dibenzo[a,h]anthracene in the rhizosphere of ryegrass (Lolium perenne L.). Biodegradation 17:511-521. Doi:10.1007/s10532-005-9022-x

DeAngelis, K.M., Brodie, E.L., DeSantis, T.Z., Andersen, G.L., Lindow, S.E., Firestone, M.K. 2009. Selective progressive response of soil microbial community to wild oat roots. ISME J. 3:168-178. Doi:10.1038/ismej.2008.103

Dequiedt, S., Saby, N.P.A., Lelievre, M., Jolivet, C., Thioulouse, J., Toutain, B., et al. 2011. Biogeographical patterns of soil molecular microbial biomass as influenced by soil characteristics and management. Glob. Ecol. Biogeog. 20:641-652. Doi: 10.1111/j.1466-8238.2010.00628.x

Edgar, R.C. 2010. Search and clustering orders of magnitude faster than BLAST. Bioinformatics 26:2460-2461. Doi: 10.1093/bioinformatics/btq461

Ettema, C.H., and Wardle, D.A. 2002. Spatial soil ecology, Trends Ecol. Evol. 17:177-183.

Fierer, N., Bradford, M.A., Jackson, R.B. 2007. Toward an ecological classification of soil bacteria. Ecology 88:1354-1364. Doi: 10.1890/05-1839

Fierer, N., and Jackson, R.B. 2006. The diversity and biogeography of soil bacterial communities. PNAS 103:626-631. Doi: 10.1073/pnas.0507535103

Fuka, M.M., Engel, M., Hagn, A., Munch, J.C., Sommer, M., Schloter, M. 2009. Changes of diversity pattern of proteolytic bacteria over time and space in an agricultural soil. Microb. Ecol. 57:391-401. Doi:10.1007/s00248-008-9416-5 
Garbeva, P., Van Elsas, J.D., Van Veen, J.A. 2008. Rhizosphere microbial community and its response to plant species and soil history. Plant Soil 302:19-32. Doi: 10.1007/s11104-007-9432-0

Gołębiewski M, Deja-Sikora E, Cichosz M, et al (2014) 16S rDNA pyrosequencing analysis of bacterial community in heavy metals polluted soils. Microb Ecol 67:635-647.

Grundmann, G.L. 2004. Spatial scales of soil bacterial diversity-the size of a clone. FEMS Microbiol. Ecol. 48:119-127. Doi: 10.1016/j.femsec.2004.01.010

Haritash, A.K., and Kaushik, C.P. 2009 Biodegradation aspects of polycyclic aromatic hydrocarbons (PAHs): a review. J. Hazard. Mat. 169:1-15. Doi: 10.1016/j.jhazmat.2009.03.137

Hinsinger, P., Bengough, A.G., Vetterlein, D., Young, I.M. 2009. Rhizosphere: biophysics, biogeochemistry and ecological relevance. Plant Soil 321:117-152. Doi:10.1007/s11104-008-9885-9

Hinsinger, P., Plassard, C., Tang, C., Jaillard, B. 2003. Origins of root-mediated pH changes in the rhizosphere and their responses to environmental constraints: A review. Plant Soil 248:43-59. Doi: 10.1023/A:1022371130939

Hybolt, T.K., Aamand, J., Johnson, A.R. 2011. Quantification of centimeter-scale spatial variation in PAH, glucose and benzoic acid mineralization and soil organic matter in road-side soil. Environ. Pollut. 159:1085-1091. Doi: 10.1016/j.envpol.2011.02.028

Jaeger, C.H., Lindow, S.E., Miller, W., Clark, E., Firestone, M.K. 1999. Mapping of sugar and amino acid availability in soil around roots with bacterial sensors of sucrose and tryptophan. Appl. Environ. Microbiol. 65:2685-2690.

Janssen, P.H. 2006. Identifying the dominant soil bacterial taxa in libraries of 16S rRNA and 16S rRNA genes. Appl. Environ. Microbiol. 72:1719-1728. Doi: 10.1128/AEM.72.3.1719-1728.2006

Johnsen, A.R., and Karlson, U. 2007. Diffuse PAH contamination of surface soils: environmental occurrence, bioavailability, and microbial degradation. Appl. Microbiol. Biotechnol. 76:533-543. Doi: 10.1007/s00253-007-1045-2

Jones, R.T., Robeson, M.S., Lauber, C.L., Hamady, M., Knight, R., Fierer, N. 2009. A comprehensive survey of soil acidobacterial diversity using pyrosequencing and clone library analyses. ISME J. 3:442-453. Doi: 10.1038/ismej.2008.127

Kanaly, R.A., and Harayama, S. 2010. Advances in the field of high molecular weight polycyclic aromatic hydrocarbon biodegradation by bacteria. Microb. Biotechnol. 3:136-164. Doi: 10.1111/j.17517915.2009.00130.x

Kawasaki, A., Watson, E.R., Kertesz, M.A. 2012. Indirect effects of polycyclic aromatic hydrocarbon contamination on microbial communities in legume and grass rhizospheres. Plant Soil 358:169-182. Doi:10.1007/s11104-011-1089-Z

Kirk, J.L., Klironomos, J.N., Lee, H., Trevors, J.T. 2005. The effects of perennial ryegrass and alfalfa on microbial abundance and diversity in petroleum contaminated soil. Environ. Pollut. 133:455-465. Doi: 10.1016/j.envpol.2004.06.002

Kowalchuk GA, Buma D, de Boer W, Klinkhamer PL, van Veen J 2002 Effects of above-ground plant species composition diversity on the diversity of soil-borne microorganisms. Antonie Van Leeuwenhoek. 81:509-520. Doi:10.1023/A:1020565523615

Kuiper, I., Lagendijk, E.L., Bloemberg, G.V., Lugtenberg, B.J. 2004. Rhizoremediation: a beneficial plantmicrobe interaction. Mol. Plant Microbe Interact. 17:6-15. Doi: 10.1094/MPMI.2004.17.1.6 
Kuske, C.R., Ticknor, L.O., Miller, M.E., Dunbar, J.M., Davis, J.A., Barns, S.M., Belnap, J. 2002. Comparison of soil bacterial communities in rhizospheres of three plant species and the interspaces in an arid grassland. Appl. Environ. Microbiol. 68:1854-1863. Doi: 10.1128/AEM.68.4.1854-1863.2002

Kuzyakov, Y., and Blagodatskaya, E. 2015. Microbial hotspots and hot moments in soil: Concept \& review. Soil Biol. Biochem. 83: 184-199. Doi: 10.1016/j.soilbio.2015.01.025

Langille, M.G.I., Zaneveld, J., Caporaso, J.G., McDonald, D., Knights, D., Reyes, J.A., et al. 2013. Predictive functional profiling of microbial communities using $16 \mathrm{~S}$ rRNA marker gene sequences. Nat. Biotech. 31:81-821. Doi:10.1038/nbt.2676

Liste, H.H., and Prutz, I. 2006 Plant performance, dioxygenase-expressing rhizosphere bacteria, and biodegradation of weathered hydrocarbons in contaminated soil. Chemosphere 62:1411-1420. Doi: 10.1016/j.chemosphere.2005.05.018

Macleod, C.J., and Semple, K.T. 2002. The adaptation of two similar soils to pyrene catabolism. Environ. Pollut. 119:357-364. Doi: 10.1016/S0269-7491(01)00343-8

Marilley, L., and Aragno, M. 1999. Phylogenetic diversity of bacterial communities differing in degree of proximity of Lolium perenne and Trifolium repens roots. Appl. Soil Ecol. 13:127-136. Doi: 10.1016/S0929-1393(99)00028-1

Marschner, P., Yang, C.H., Lieberei, R., Crowley, D.E. 2001. Soil and plant specific effects on bacterial community composition in the rhizosphere. Soil Biol. Biochem. 33:1437-1445. Doi: 10.1016/S00380717(01)00052-9

Marschner, P., Neumann, G., Kania, A., Weiskopf, L., Lieberei, R. 2002. Spatial and temporal dynamics of the microbial community structure in the rhizosphere of cluster roots of white lupin (Lupinus albus L.). Plant Soil 246:167-174. Doi:10.1023/A:1020663909890

McDonald, D., Price, M.N., Goodrich, J., Nawrocki, E.P., DeSantis, T.Z., Probst, A., et al. 2012. An improved Greengenes taxonomy with explicit ranks for ecological and evolutionary analyses of bacteria and archaea. ISME J. 6:610-618. Doi:10.1038/ismej.2011.139

Mukherjee, S., Juottonen, H., Siivonen, P., Lloret Quesada, C., Tuomi, P., Pulkkinen, P., Yrjala, K. 2014. Spatial patterns of microbial diversity activity in an aged creosote-contaminated site. ISME J. 8:2131-2142. Doi:10.1038/ismej.2014.151

Nacke, H., Thürmer, A., Wollherr, A., Will, C., Hodac, L., Herold, N., Schöning, I., Schrumpf, M., Daniel, R. (2011) Pyrosequencing-based assessment of bacterial community structure along different management types in German forest and grassland soils. PlosOne 6(2): e17000. Doi : 10.1371/journal.pone.0017000

Nakagawa, S., and Cuthill, I.C. 2007. Effect size, confidence interval and statistical significance: a practical guide for biologists. Biol. Rev. 82:591-605. Doi: 10.1111/j.1469-185X.2007.00027.x

Naveed, M., Herath, L., Moldrup, P., Arthur, E., Nicolaisen, M., Norgaard, T., et al. 2016. Spatial variability of microbial richness and diversity and relationships with soil organic carbon, texture and structure across an agricultural field. Appl. Soil Ecol. 103:44-55. Doi: 10.1016/j.apsoil.2016.03.004

Nemergut, D.R., Anderson, S.P., Cleveland, C.C., Martin, A.P., Miller, A.E., Seimon, A., Schmidt, S.K. 2007. Microbial community succession in an unvegetated, recently deglaciated soil. Microb. Ecol. 53: 110-122. Doi:10.1007/s00248-006-9144-7 
Nunan, N., Wu, K., Young, I.M., Crawford, J.W., Ritz, K. 2002. In situ spatial patterns of soil bacterial populations, mapped at multiple scales, in an arable soil. Microb. Ecol. 44:296-305. Doi: 10.1007/s00248-002-2021-0

O'Brien, S.L., Gibbons, S.M., Owens, S.M., Hampton Marcell, J., Johnston, E.R., Jastrow, J.D., et al. 2016. Spatial scale drives patterns in soil bacterial diversity. Environ Microbiol 18:2039-2051. Doi: $10.1111 / 1462-2920.13231$

Oksanen, J., Blanchet, F.G., Kindt, R., Legendre, P., Minchin, P.R., O’Hara, R., et al. 2013. Package “vegan.” R Packag Ver 254:20-8.

Oliveira, V., Gomes, N., Almeida, A., Silva, A., Simões, M.M., Smalla, K., Cunha, Â. 2014. Hydrocarbon contamination and plant species determine the phylogenetic and functional diversity of endophytic degrading bacteria. Mol. Ecol. 23:1392-1404. Doi: 10.1111/mec.12559

Ouvrard, S., Barnier, C., Bauda, P., Beguiristain, T., Biache, C., Bonnard, M., et al. 2011. In situ assessment of phytotechnologies for multicontaminated soil management. Int. J. Phytorem. 13:245-263. Doi: 10.1080/15226514.2011.568546

Parks, D.H., and Beiko, R.G. 2010. Identifying biologically relevant differences between metagenomic communities. Bioinformatics 26:715-721. Doi: 10.1093/bioinformatics/btq041

Peng, C., Wang, M., Chen, W. 2016. Spatial analysis of PAHs in soils along an urban-suburban-rural gradient:scale effect, distribution patterns, diffusion and influencing factors. Sci. Rep. 6:37185. Doi: $10.1038 /$ srep37185.

Philippot, L., Raaijmakers, J.M., Lemanceau, P., van der Putten, W.H. 2013. Going back to the roots: the microbial ecology of the rhizosphere. Nature Rev. Microbiol 11:789-799. Doi: 10.1038/nrmicro3109

Raynaud, X., and Nunan, N. 2014. Spatial ecology of bacteria at the microscale in soil. PLoS One, 9:e87217. Doi: 10.1371 /journal.pone.0087217

Remenant, B., Grundmann, G.L., Jocteur-Monrozier, L. 2009. From the micro-scale to the habitat: assessment of soil bacterial community structure as shown by soil structure directed sampling. Soil Biol. Biochem. 41:29-36. Doi: 10.1016/j.soilbio.2008.09.005

Rousk, J., Baath, E., Brookes, P.C., Lauber, C.L., Lozupone, C., Caporaso, J.G., Knight, R., Fierer, N. 2010. Soil bacterial and fungal communities across a pH gradient in an arable soil. ISME J. 4:1340-1351. Doi:10.1038/ismej.2010.58

Schmidt, H., Eickhorst, T. 2013. Spatio-temporal variability of microbial abundance and community structure in the puddled layer of a paddy soil cultivated with wetland rice (Oryza sativa L.). Appl. Soil Ecol. 72:93102. Doi: 10.1016/j.apsoil.2013.06.002

Schmidt, H., Eickhorst, T. 2014. Detection and quantification of native microbial populations on soil-grown rice roots by catalyzed reporter deposition-fluorescence in situ hybridization. FEMS Microbiol. Ecol. 87:390402. Doi: $10.1111 / 1574-6941.12232$

Shannon, P., Markiel, A., Ozier, O., Baliga, N.S., Wang, J.T., Ramage, D., et al. 2003. Cytoscape: a software environment for integrated models of biomolecular interaction networks. Genome Res. 13:2498-2504.

Siciliano, S.D., Germida, J.J., Banks, K., Greer, C.W. 2003. Changes in microbial community composition and function during a polyaromatic hydrocarbon phytoremediation field trial. Appl. Environ. Microbiol. 69:483-489. Doi: 10.1128/AEM.69.1.483-489.2003 
Smalla, K., Wiel, G., Buchner, A., Zock, A., Parzy, J., Kaiser, S., et al. 2001. Bulk and rhizosphere soil bacterial communities studied by denaturing gradient gel electrophoresis: plant-dependent enrichment and seasonal shifts revealed. Appl. Environ. Microbiol. 67:4742-4751. Doi: 10.1128/AEM.67.10.4742-4751.2001

Soleimani, M, Afyuni, M, Hajabbasi, MA, Nourbakhsh, F, Sabzalian, MR, Christensen, JH 2010. Phytoremediation of an aged petroleum contaminated soil using endophyte infected and non-infected grasses. Chemosphere. 81:1084-1090. Doi : 10.1016/j.chemosphere.2010.09.034

Stolpovsky, K., Gharasoo, M., Thullner, M. 2012. The impact of pore-size heterogeneities on the spatiotemporal variation of microbial metabolic activity in porous media. Soil Sci. 177:98-110. Doi: 10.1097/SS.0b013e318241105d

Tarlera, S., Jangid, K., Ivester A.H., Whitman, W.B., Williams, M.A. 2008. Microbial community succession and bacterial diversity in soils during 77000 years of ecosystem development. FEMS Microbiol. Ecol. 64 :129-140. Doi : 10.1111/j.1574-6941.2008.00444.x

Thomas, F., and Cébron, A. 2016. Short-term rhizosphere effect on available carbon sources, phenanthrene degradation, and active microbiome in an aged-contaminated industrial soil. Front. Microbiol. 7:92. Doi:10.3389/fmicb.2016.00092

Tripathi, B.M., Lee-Cruz, L., Kim, M., Singh, D., Go, R., Shukor, N.A.A., et al. 2014. Spatial scaling effects on soil bacterial communities in Malaysian tropical forests. Microb. Ecol. 68: 247-258. Doi:10.1007/s00248014-0404-7

Turner, S., Pryer, K.M., Miao, V.P., Palmer, J.D. 1999. Investigating deep phylogenetic relationships among cyanobacteria and plastids by small subunit rRNA sequence analysis. .J Eukaryot. Microbiol. 46:327338. Doi: 10.1111/j.1550-7408.1999.tb04612.x

Uteau, D., Hafner, S., Pagenkemper, S.K., Peth, S., Wiesenberg, G.L., Kuzyakov, Y., Horn, R. 2015. Oxygen and redox potential gradients in the rhizosphere of alfalfa grown on a loamy soil. J. Plant Nut. Soil Sci. 178:278-287. Doi: 10.1002/jpln.201300624

Walker, T.S., Bais, H.P., Grotewold, E., Vivanco, J.M. 2003. Root exudation and rhizosphere biology. Plant Physiol. 132:44-51. Doi: 10.1104/ pp. 102. 019661

Wang, Q., Garrity, G.M., Tiedje, J.M., Cole, J.R. 2007. Naïve bayesian classifier for rapid assignment of rRNA sequences into the new bacterial taxonomy. Appl. Environ. Microbiol. 73:5261-5267. Doi: 10.1128/AEM.00062-07

Xia, L.C., Steele, J.A., Cram, J.A., Cardon, Z.G., Simmons, S.L., Vallino, J.J., et al. 2011. Extended local similarity analysis (eLSA) of microbial community and other time series data with replicates. BMC Syst. Biol. 5:1-12. Doi: 10.1186/1752-0509-5-S2-S15

Yang, C.H., and Crowley, D.E. 2000. Rhizosphere microbial community structure in relation to root location and plant iron nutritional status. Appl. Environ. Microbiol. 66:345-351. 10.1016/S0038-0717(01)00052-9

Yang S, Wen X, Zhao L, Shi Y, Jin H (2014a) Crude oil treatment leads to shift of bacterial communities in soils from the deep active layer and upper permafrost along the China-Russia Crude Oil Pipeline route. PloS one 9:e96552. Doi : 10.1371/journal.pone.0096552

Yang Y, Wang J, Liao J, et al (2014b) Distribution of Naphthalene Dioxygenase Genes in Crude OilContaminated Soils. Microb Ecol 68:785-793. doi: 10.1007/s00248-0140457-7 
688 Yergeau, E., Bokhorst, S., Kang, S., Zhou, J., Greer, C.W., Aerts, R., Kowalchuk, G.A. 2012. Shifts in soil 689 microorganisms in response to warming are consistent across a range of Antarctic environments. ISME J. 6:692-702. Doi:10.1038/ismej.2011.124

691 Yergeau, E., Sanschagrin, S., Maynard, C., St-Arnaud, M., Greer, C.W. 2014. Microbial expression profiles in 692 the rhizosphere of willows depend on soil contamination. ISME J. 8:344-358. Doi: 693 10.1128/AEM.67.10.4742-4751.2001

694 Yrjälä, K., Keskinen, A.K., Åkerman, M.L., Fortelius, C., Sipilä, T.P. 2010. The rhizosphere and PAH 695 amendment mediate impacts on functional and structural bacterial diversity in sandy peat soil. Environ. 696 Pollut. 158:1680-1688. Doi:10.1016/j.envpol.2009.11.026

697

698 


\section{Canadian Journal of Microbiology}

Tables

Table 1. Bacterial richness and diversity estimators in soil planted with alfalfa (Alf) or ryegrass (Rye) after 37 days (T37) of plant growth, at four depths $(2,8,14$ and $20 \mathrm{~cm}$ from the surface of the rhizobox). OTUs were created with $97 \%$ sequence similarity $\left(\mathrm{OTU}_{97}\right)$. Means $\pm \mathrm{SD}, \mathrm{n}=4$. The effect of plant species was evaluated using Student t-tests $(\mathrm{p}<0.05)$. The effect of depth was tested (different letters $(a, b, c)$ denote groups with significantly different values $(\mathrm{p}<0.05))$ separately for each plant species using one-way ANalyses Of VAriance (ANOVA) followed by Tukey HSD multiple comparison tests.

707

\begin{tabular}{|c|c|c|c|c|c|}
\hline \multirow[b]{2}{*}{ Conditions } & \multicolumn{2}{|l|}{$\begin{array}{l}\text { Richness } \\
\text { estimator }\end{array}$} & \multicolumn{3}{|l|}{$\begin{array}{l}\text { Diversity } \\
\text { estimator }\end{array}$} \\
\hline & $\begin{array}{l}\text { Observed } \\
\text { OTU }_{97}\end{array}$ & Chaol & $\begin{array}{l}\text { Shannon's index } \\
\left(\mathrm{H}^{\prime}\right)\end{array}$ & $\begin{array}{l}\text { Inverse of } \\
\text { Simpson's } \\
\text { (1/D) }\end{array}$ & Evenness (E) \\
\hline Alf_T37-2 & $351 \pm 7^{b}$ & $519 \pm 33^{c}$ & $6.42 \pm 0.11^{b}$ & $29.78 \pm 4.50^{b}$ & $0.759 \pm 0.012^{b}$ \\
\hline Alf T37-8 & $375 \pm 22^{b}$ & $581 \pm 57^{\mathrm{bc}}$ & $6.64 \pm 0.27^{a b}$ & $42.02 \pm 13.88^{a b}$ & $0.777 \pm 0.024^{\mathrm{ab}}$ \\
\hline Alf_T37-14 & $389 \pm 25^{\mathrm{ab}}$ & $629 \pm 57^{\mathrm{ab}}$ & $6.70 \pm 0.19^{a b}$ & $42.08 \pm 7.47^{\mathrm{ab}}$ & $0.779 \pm 0.014^{\mathrm{ab}}$ \\
\hline Alf T37-20 & $415 \pm 15^{a}$ & $723 \pm 52^{a}$ & $6.92 \pm 0.13^{\mathrm{a}}$ & $54.10 \pm 10.01^{\mathrm{a}}$ & $0.796 \pm 0.013^{\mathrm{a}}$ \\
\hline Rye T37-2 & $415 \pm 10^{\mathrm{ab}}$ & $684 \pm 76$ & $6.91 \pm 0.14$ & $53.31 \pm 9.44$ & $0.795 \pm 0.017$ \\
\hline Rye_T37-8 & $415 \pm 7^{\mathrm{ab}}$ & $707 \pm 47$ & $6.99 \pm 0.07$ & $60.06 \pm 8.95$ & $0.804 \pm 0.008$ \\
\hline Rye T37-14 & $396 \pm 5^{b}$ & $619 \pm 70$ & $6.85 \pm 0.14$ & $50.65 \pm 8.66$ & $0.793 \pm 0.016$ \\
\hline Rye-T37-20 & $434 \pm 14^{\mathrm{a}}$ & $722 \pm 39$ & $6.96 \pm 0.08$ & $56.98 \pm 5.11$ & $0.795 \pm 0.007$ \\
\hline Plant effect & Rye $>$ Alf & Rye $>$ Alf & Rye $>$ Alf & Rye $>$ Alf & Rye $>$ Alf \\
\hline
\end{tabular}


711 Table 2. Bacterial taxa (at the phylum, class, order and OTU levels) for which significant effect of the plant 712 species was detected on their relative abundance after 37 days of plant growth. Mean \pm SD $(n=16)$ over the entire 713 depth profile. The effect of plant was evaluated using Welch's t-tests followed by Benjamini-Hochberg 714 correction of the p-values. Significant taxa were defined based on stringent criteria: abundance (at least 3 715 sequences in one sample), corrected $\mathrm{p}$-value $(\mathrm{q}<0.05)$ and effect size (difference between proportions $>1$ or ratio 716 of proportions $>4$ ). Based on these statistical analyses, values in boldface denote the group with significantly highest relative abundance for each taxon.

\begin{tabular}{|c|c|c|c|}
\hline \multirow[t]{2}{*}{ Bacterial taxa } & & \multicolumn{2}{|c|}{ Relative abundance (\%) } \\
\hline & & Alf_T37 & Rye_T37 \\
\hline \multicolumn{4}{|l|}{ Phylum level } \\
\hline Bacteroidetes & & $6.6 \pm 2.5$ & $2.5 \pm 0.8$ \\
\hline Chloroflexi & & $3.1 \pm 0.8$ & $4.4 \pm 0.6$ \\
\hline Firmicutes & & $2.3 \pm 1.0$ & $1.3 \pm 0.3$ \\
\hline Proteobacteria & & $60.1 \pm 5.4$ & $64.7 \pm 4.2$ \\
\hline \multicolumn{4}{|l|}{ Class level } \\
\hline Acidimicrobiia & (Actinobacteria) & $3.0 \pm 1.0$ & $4.5 \pm 0.7$ \\
\hline Flavobacteriia & (Bacteroidetes) & $3.6 \pm 2.2$ & $0.4 \pm 0.3$ \\
\hline Bacilli & (Firmicutes) & $2.1 \pm 1.0$ & $0.9 \pm 0.2$ \\
\hline Alphaproteobacteria & (Proteobacteria) & $25.7 \pm 2.0$ & $30.5 \pm 2.5$ \\
\hline Betaproteobacteria & & $11.0 \pm 2.7$ & $15.9 \pm 3.4$ \\
\hline Gammaproteobacteria & & $22.6 \pm 4.2$ & $17.7 \pm 3.2$ \\
\hline \multicolumn{4}{|l|}{ Order level } \\
\hline Acidimicrobiales & (Actinobacteria) & $3.0 \pm 1.0$ & $4.5 \pm 0.7$ \\
\hline Flavobacteriales & (Bacteroidetes) & $3.6 \pm 2.2$ & $0.4 \pm 0.3$ \\
\hline Bacillales & (Firmicutes) & $2.1 \pm 1.0$ & $0.9 \pm 0.2$ \\
\hline Sphingomonadales & (Alphaproteobacteria) & $11.6 \pm 1.7$ & $16.0 \pm 2.6$ \\
\hline Caulobacterales & & $1.9 \pm 0.3$ & $3.1 \pm 0.6$ \\
\hline Burkholderiales & (Betaproteobacteria) & $4.3 \pm 0.9$ & $6.1 \pm 1.4$ \\
\hline Hydrogenophilales & & $5.8 \pm 2.0$ & $8.8 \pm 2.2$ \\
\hline Pseudomonadales & (Gammaproteobacteria) & $7.4 \pm 2.8$ & $3.1 \pm 1.3$ \\
\hline \multicolumn{4}{|l|}{ OTU level } \\
\hline Unclass. Micrococcaceae_1 & (Actinobacteria) & $6.1 \pm 4.6$ & $0.6 \pm 0.6$ \\
\hline Unclass. Micrococcaceae_2 & & $0.1 \pm 0.1$ & $0.01 \pm 0.02$ \\
\hline Paenibacillus & (Firmicutes) & $0.4 \pm 0.3$ & $0.01 \pm 0.01$ \\
\hline Unclass. Caulobacteraceae_1 & (Alphaproteobacteria) & $0.2 \pm 0.1$ & $0.01 \pm 0.02$ \\
\hline Unclass. Caulobacteraceae_2 & & $0.17 \pm 0.1$ & $0.002 \pm 0.01$ \\
\hline Mycoplana & & $0.7 \pm 0.2$ & $1.9 \pm 0.5$ \\
\hline Devosia & & $2.6 \pm 1.3$ & $0.4 \pm 0.3$ \\
\hline Unclass. Sphingomonadaceae_1 & & $0.6 \pm 0.5$ & $0.03 \pm 0.04$ \\
\hline Unclass. Sphingomonadaceae_2 & & $1.1 \pm 0.4$ & $3.0 \pm 0.3$ \\
\hline Thiobacillus & (Betaproteobacteria) & $3.6 \pm 1.1$ & $5.7 \pm 1.8$ \\
\hline Pseudomonas & (Gammaproteobacteria) & $6.7 \pm 2.9$ & $1.7 \pm 0.7$ \\
\hline
\end{tabular}




\section{Canadian Journal of Microbiology}

\section{Figure caption}

721

722

723

Figure 1. Relative abundance of the bacterial phyla (represented by at least 3 sequences) after 37 days (T37) of alfalfa (Alf) and ryegrass (Rye) growth for samples (means, $\mathrm{n}=4)$ located at four depths $(2,8,14$ and $20 \mathrm{~cm}$ from the surface of the rhizobox). Proteobacteria were represented at the class level for better taxonomic resolution. The group named other phyla includes: MVP-21, OD1, SBR1093, TM6, and TM7.

Figure 2. Non-metric multidimensional scaling ordination (nMDS) representing the impact of environmental factors (arrows: edaphic parameters in black, sugar content in green, rhizospheric parameters in green and bacterial abundance in red) on bacterial community assemblage in alfalfa (circle) and ryegrass (triangle) rhizospheres at four depths (color gradients) after 37 days of plant growth. Each arrow represents one environmental parameter significantly correlated to the bacterial diversity $\left(p<0.05\right.$ and $\left.R^{2}>0.2\right)$, excepted for PAHs ( $\mathrm{p}=0.441$ and $\left.\mathrm{R}^{2}=0.0511\right)$ and bioavailable PAHs $\left(\mathrm{p}=0.477\right.$ and $\left.\mathrm{R}^{2}=0.0514\right)$. The nMDS $2 \mathrm{D}$-stress was 0.161 .

Figure 3. OTUs for which significant effect of depth was detected on their relative abundance in alfalfa rhizosphere. A Tukey-Kramer ANOVA with Benjamini-Hochberg correction of p-value (q-value) allowed identifying OTUs with significant (considering $\mathrm{q}<0.05$, and effect size $>0.26)$ differences with depth $(2,8,14$ and $20 \mathrm{~cm}$ from the surface of the rhizobox $)$. Means $\pm \mathrm{SD}(\mathrm{n}=4)$. For each OTU, letters denote groups with significant differences in relative abundance. 


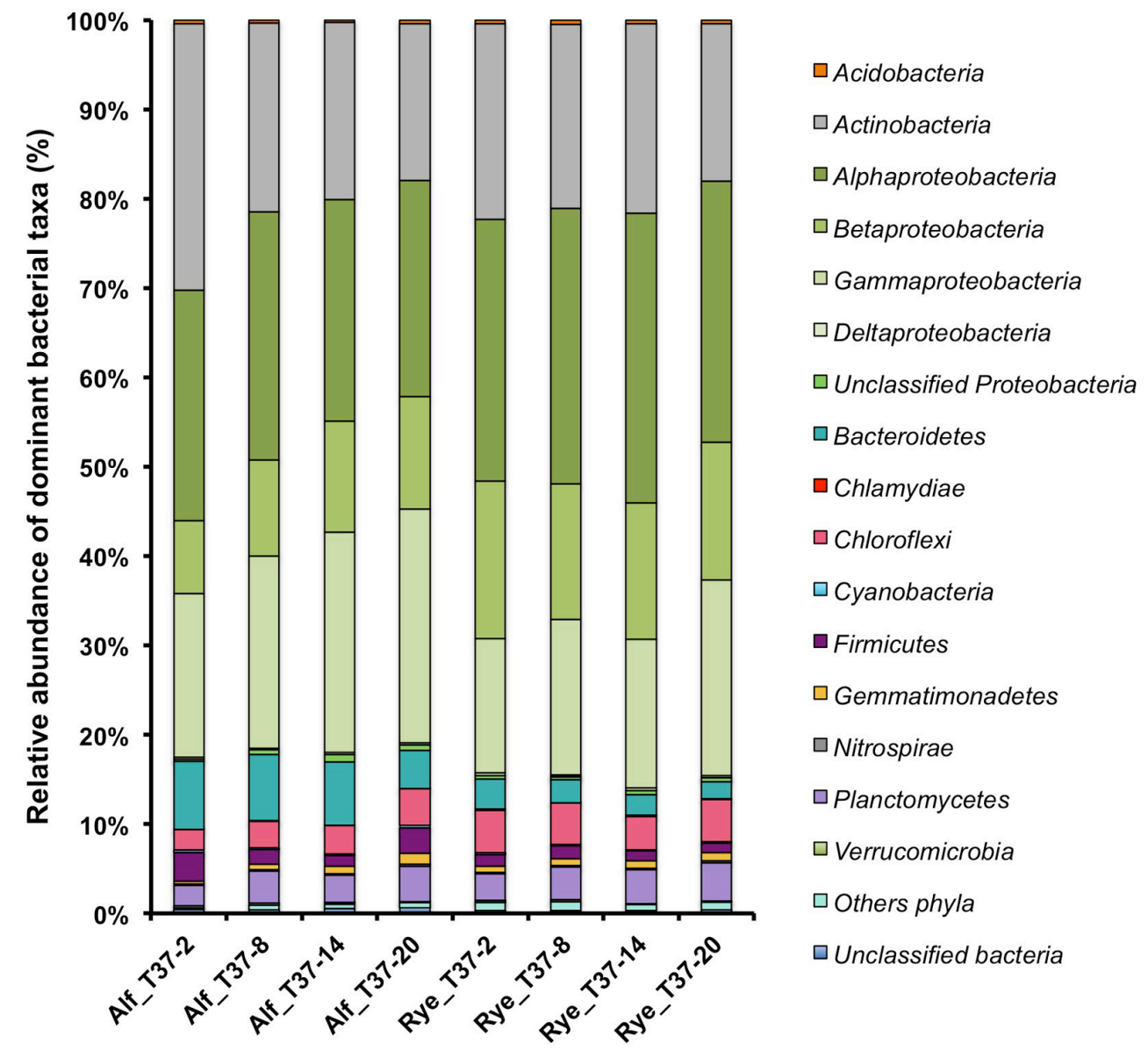




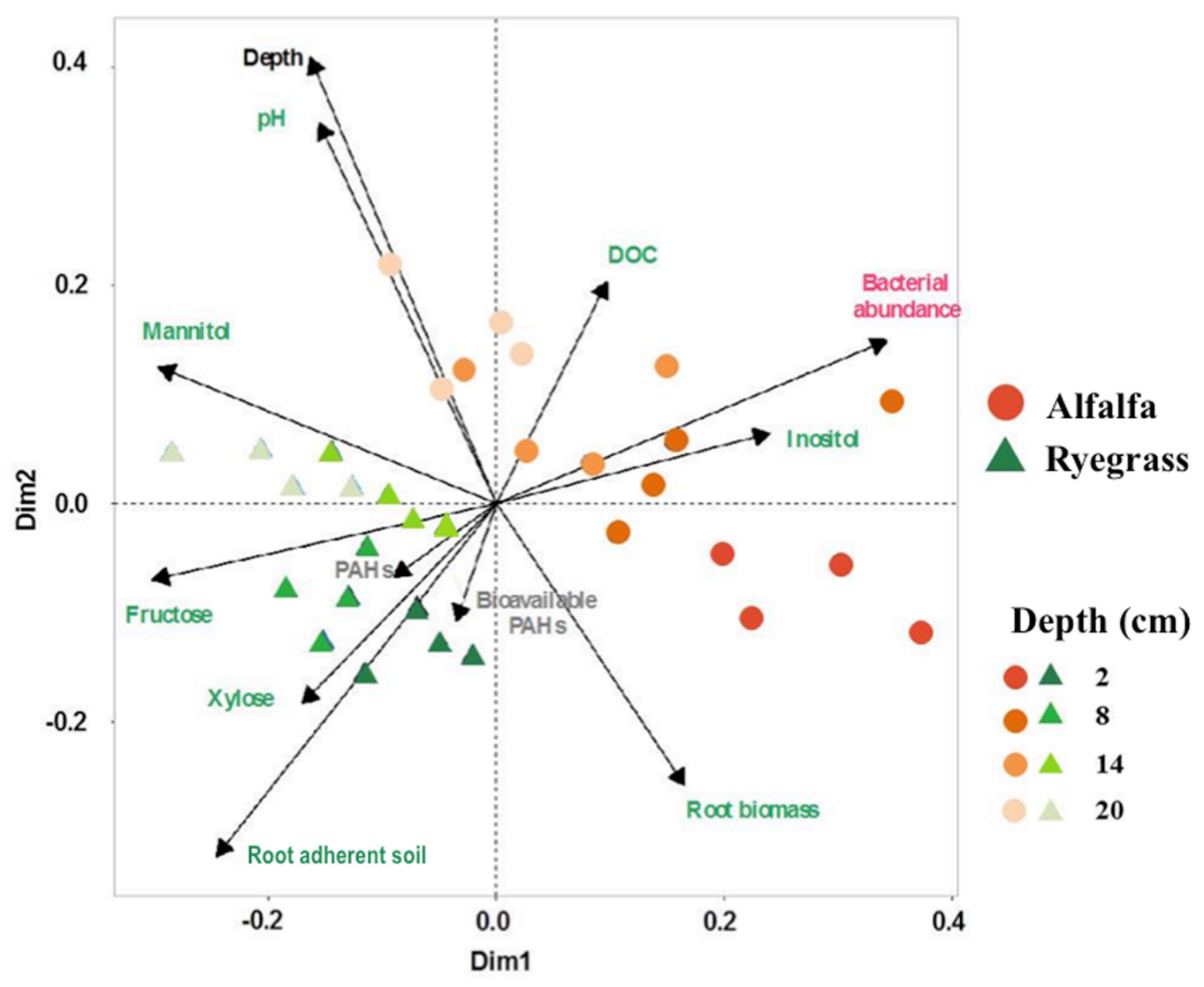




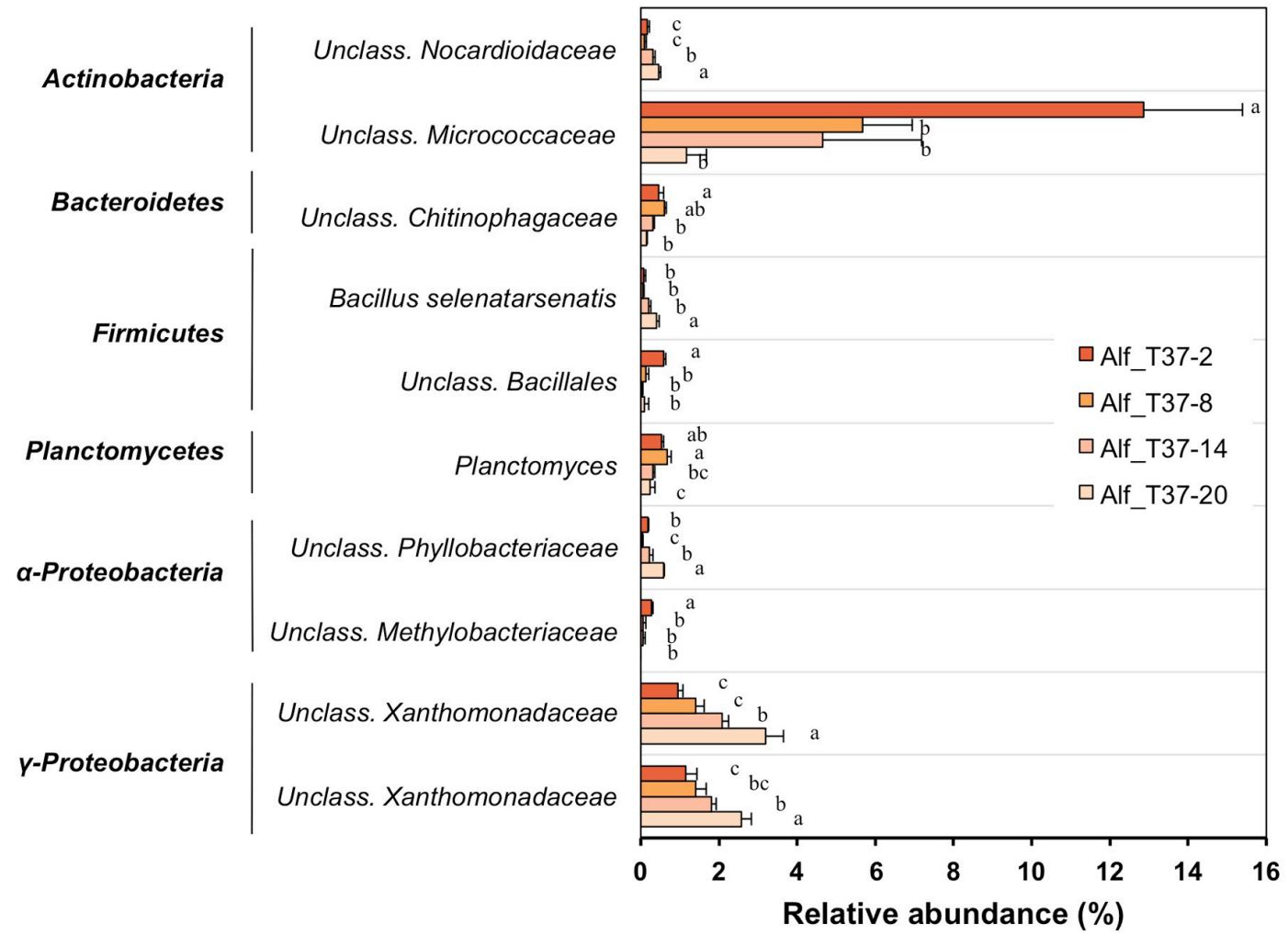

